\title{
EFFECT OF COLD PLASMA ON WHEAT FLOUR AND BREAD MAKING QUALITY
}

\author{
Mirjana Menkovska ${ }^{1}$, Mariya Mangova ${ }^{2 *}$, Krasen Dimitrov $^{3}$ \\ 1 "Ss. Cyril and Methodius" University in Skopje, Institute of Animal Science, \\ Blvd. Ilinden 92a, 1000 Skopje, Republic of Macedonia \\ ${ }^{2}$ Institute of Plant Genetic Resources, Blvd "Drujba”" № 2, 4122, Sadovo, Bulgaria \\ ${ }^{3}$ MAMEL Ltd, "8- ${ }^{\text {th }}$ November" Str. 8, 9000, Varna, Bulgaria \\ *corresponding author Mariya Mangova: blend_bg@yahoo.com
}

\begin{abstract}
Cold plasma is an environmentally friendly technology that meets the present ecological requirements. Plasma is not accumulated in end-used products. As the cold plasma is produced just before usage, there are no requirements either for storage or activation procedure. Cold plasma has an oxidation-reduction potential. In the bread baking industry it is used in dough systems to whiten the flour and subsequent bread crumb. Also to promote disulfide bond formation between glutenin proteins, that improves dough strength. Experiments have been realized to evaluate the influence of cold plasma treatment on the flour and bread-making quality without the use of any additives. Wheat flour was treated with cold plasma in counter flow exchange by using the device "Plason". Exposure: concentration of $1000 \mathrm{ppm}$ at $2.5 \mathrm{~L} /$ minute. Time exposition: 45 minutes. Because gas dissociates quickly into molecular oxygen the assessment of wheat flour was made first just after treatment, and then five days later. As a result of cold plasma treatment, the treated flour has a brightly creamy color, unlike untreated flour. The content of wet gluten has gone down a little due to deterioration of its hydration capacity but gluten quality was increased. Improvements in dough structural and mechanical properties such as, increasing dough stability and dough strength, reduction of dough softening, all have been observed. The results obtained showed that cold plasma has an effect on bread structural and mechanical properties. The loaves baked just after treatment demonstrated expansion of the total and specific volume along with enhancement of their appearance and porosity structure.
\end{abstract}

Key words: wheat flour; cold plasma; gluten; bread making properties

\section{ЕФЕКТ НА ЛАДНАТА ПЛАЗМА ВРЗ КВАЛИТЕТОТ НА ПЧЕНИЧНО БРАШНО И ПЕКАРСКИОТ ЛЕБ}

Ладната плазма е технологија која ги задоволува сегашните еколошки барања. Плазмата не е акумулирана во крајните производи. Бидејќи ладната плазма се произведува непосредно пред примена, нема потреба од складирање или процедури за активирање. Ладната плазма има оксидационо-редукционен потенцијал. Во пекарската лебна индустрија се користі за белење на брашното за теста и последователно на кората на лебот. Исто така поттикнува создавање на дисулфидната врска помеѓу глутенските протеини, што ја подобрува јачината на тестото. Експериментите се реализирани за да се оцени влијанието на третирањето со ладна плазма врз брашното и квалитетот на лебот без користење на кои било адитиви. Пченичното брашно беше третирано со ладна плазма користејќ ја справата “Plason”. Експозиција: концентрација од 1000 ppm во 2,5 литри/минута. Временска експозиција: 45 минути. Бидејќи гасот дисоцира брзо во молекуларен кислород, оценувањето на пченичното брашно прво беше направено веднаш по третманот, а потоа пет дена подоцна. Како резултат на третирањето со ладна плазма, третираното брашно има светла кремаста боја, за разлика од нетретираното брашно. Содржината на влажен глутен малку се намали поради влошување на неговиот хидратационен капацитет, но квалитетот на глутенот се зголеми. Подобрување на структурните и механичките својства како што се зголемувањето на стабилноста и јачината на тестото, намалување на омекнување на тестото, сите тие беа набљудувани. Добиените резултати покажаа дека ладната плазма има ефект врз структурните и механичките својства. Векните леб печени веднаш по третманот покажаа зголемување на вкупниот и специфичниот волумен заедно со подобрување на нивниот изглед и порозната структура.

Клучни зборови: пченично брашно; ладна плазма; глутен; својства на произведен леб 


\section{INTRODUCTION}

Cld plasma has advantages over other traditional oxidants. It is an environmentally friendly technology that meets the present ecological requirements. Plasma decomposes rapidly (half-life of 20-50 minutes) to molecular oxygen; leaves no residue; not accumulated in end-used products. As it is produced just before usage, there are no requirements either for storage or activation procedure. Cold plasma has an oxidation-reduction potential. In the baking industry it is used in bread dough systems to whiten the flour and subsequent bread crumb. According to Sandhu et al. [1], plasma treatment oxidizes lipids, increases brightness and reduces the yellow hue of flour, and increases peak viscosity and setback viscosity of flour. Also it promotes disulfide bond formation between glutenin proteins, which improves dough strength. Chittrakorn [3] reported that cakes baked from common wheat flour treated by plasma $(0.06$ $1 /$ min for $36 \mathrm{~min}$ ) had larger volume and softer texture than those produced from the chlorinated flour. These results suggest that cold plasma could be used as an oxidizing agent in baking systems. However, information on application of plasma treatment is very limited especially for bread making.

Experiments have been realized to evaluate the influence of cold plasma treatment on the flour and bread-making quality without the use of any additives.

\section{MATERIAL AND METHODS}

Grain of wheat variety "Enola" (T. aestivum) was conditioned of at $16 \%$ moisture content for 18 $\mathrm{hr}$, then milled with MLU 202 Buhler mill to $70 \%$ flour extraction. The flour was treated with cold plasma in counter flow exchange using the "Plason"-Mamel Ltd showed in Figure 1 and Figure 2. This device is twice as powerful as ozone gas generators. Exposure: concentration of 1000 $\mathrm{ppm}$ at $2.5 \mathrm{1} / \mathrm{min}$. Recommended exposure time by the company: $30 \mathrm{~min}$ and $45 \mathrm{~min}$.

The term "cold plasma" in this specification is used to indicate a condition in which the charged particles of a substance have been dissociated to form of ionized gas by an extremely high level of energy applied to the substance. The quality of flour samples was evaluated just after treatment because of the quickly gas decomposition into molecular oxygen.
It were determined sedimentation value, content and quality of wet gluten, rheological properties of dough, by using devices such as Alveograph - Chopin, Farinograph - Brabender as well as bread making quality of untreated and treated wheat flour .

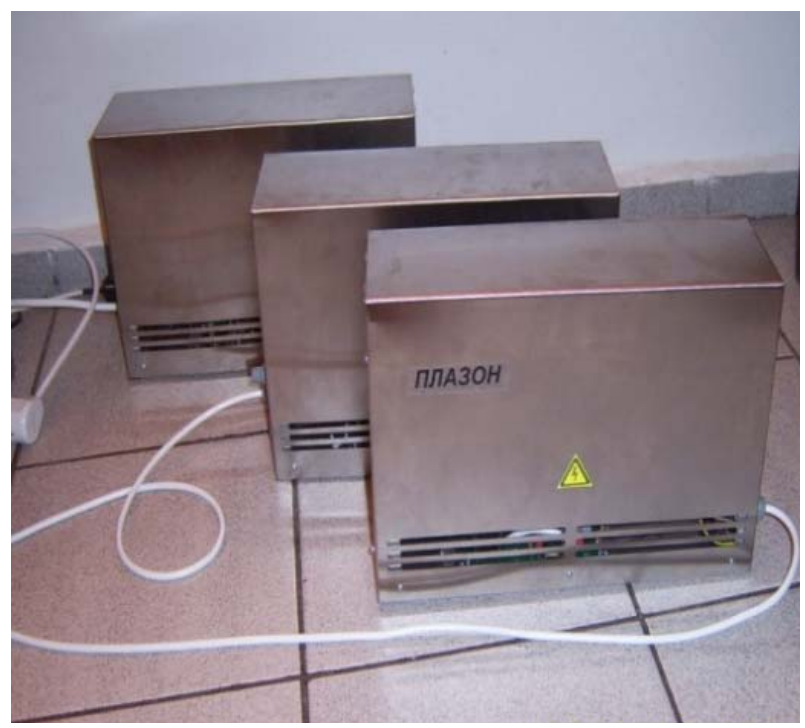

Fig. 1. Device Plason - here (Mariya)

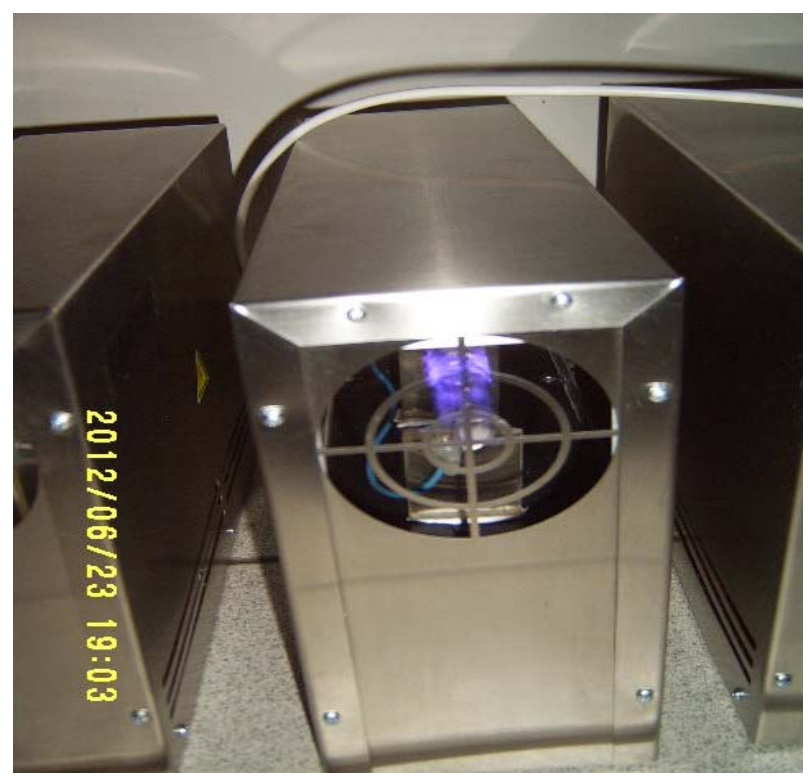

Fig. 2.. Device Plason in action

\section{RESULTS AND DISCUSSION}

Treated flour with cold plasma for $30 \mathrm{~min}$ as well as for $45 \mathrm{~min}$ had a brightly creamy color, unlike untreated flour. The content of wet gluten has a little gone down due to deterioration of its 
hydration capacity. Treatment with cold plasma for both exposure times presented better quality of wet gluten as a result of decreasing gluten softening and improving of bread making strength index (Table 1).

Protein oxidation by cold plasma is the main suggested phenomenon which could explain the modification of protein solubility and technological properties of flours. According to Sandhu et al. [1] disulfide bonds play a major role in determining dough properties. Exposure to oxidants can increase dough strength by the oxidation of sulphydryl groups to disulfide bonds. Using devices Farinograph and Alveograph in this study was reg- istered improvement in dough behavior during mixing. Increasing dough stability and dough strength, reduction of dough softening, increasing of deformation energy (W) as well as index of swelling, all have been observed in comparison with control sample Treated samples in Table 2 exhibited deformation energy, $W=254 \mathrm{~J} \cdot 10^{-4}$ and $W=280 \mathrm{~J} \cdot 10^{-4}$. Violleau et al. [2] also reported that ozonation of wheat grain had led to flour with higher force and tenacity and lower extensibility than the control; an increasing of $W$, and elasticity/extensibility configuration ratio $(\mathrm{P} / \mathrm{L})$ were observed. Nevertheless, cold plasma treatment had to be moderated.

Table 1

Effect of cold plasma on chemical-technological quality of flour

\begin{tabular}{lccccc}
\hline \hline Wheat flour & $\begin{array}{c}\text { Sedimentation value } \\
\left(\mathrm{cm}^{3}\right)\end{array}$ & $\begin{array}{c}\text { Wet gluten } \\
(\%)\end{array}$ & $\begin{array}{c}\text { Dry gluten } \\
(\%)\end{array}$ & $\begin{array}{c}\text { Gluten softening } \\
(\mathrm{mm})\end{array}$ & $\begin{array}{c}\text { Bread making } \\
\text { strength index }\end{array}$ \\
\hline Control (untreated) & 56 & 34,2 & 9,7 & 13.0 & 50 \\
Treated 30 min & 61 & 33.3 & 8,3 & 9.5 & 58 \\
Treated 45 min & 61 & 32.1 & 7.9 & 10.0 & 56 \\
\hline \hline
\end{tabular}

Table 2

Effect of cold plasma on rheological properties of dough

\begin{tabular}{lcccc|ccc}
\hline \hline & \multicolumn{4}{c|}{ Farinograph - Brabender } & \multicolumn{3}{c}{ Alveograph - Chopin } \\
\cline { 2 - 8 } Wheat flour & $\begin{array}{c}\text { Water } \\
\text { absorption } \\
(\%)\end{array}$ & $\begin{array}{c}\text { Dough formation } \\
\text { and stability } \\
(\mathrm{min})\end{array}$ & $\begin{array}{c}\text { Softening } \\
\text { of dough } \\
(\mathrm{B} . \mathrm{U}) .\end{array}$ & $\begin{array}{c}\text { Valorimetric } \\
\text { value } \\
(\mathrm{B} . \mathrm{U} .)\end{array}$ & $\begin{array}{c}\text { Deformation } \\
\text { energy } \\
\left(\mathrm{J} \cdot 10^{-4}\right)\end{array}$ & $\begin{array}{c}\text { Elasticity/Extensibility } \\
\text { P/L configuration ratio }\end{array}$ & $\begin{array}{c}\text { Index } \\
\text { of swelling }\end{array}$ \\
\hline Control (untreated) & 60.0 & 7.30 & 100 & 54 & 230.0 & 1.6 & 14.1 \\
Treated 30 min & 63.0 & 8.25 & 80 & 65 & 254.0 & 1.2 & 16.2 \\
Treated 45 min & 63.0 & 8.57 & 80 & 69 & 280.0 & 1.2 & 16.0 \\
\hline \hline
\end{tabular}

Table 3

Effect of cold plasma on bread making quality

\begin{tabular}{lccc}
\hline \hline Wheat flour & $\begin{array}{c}\text { Specific loaf volume } \\
\left(\mathrm{cm}^{3} / \mathrm{g}\right)\end{array}$ & $\begin{array}{c}\text { Total loaf volume } \\
\left(\mathrm{cm}^{3}\right)\end{array}$ & $\begin{array}{c}\text { Shape formation ratio } \\
(\mathrm{h} / \mathrm{d})\end{array}$ \\
\hline Control (untreated) & 3.79 & 560 & 0.47 \\
Treated 30 min & 4.46 & 620 & 0.52 \\
Treated 45 min & 4.55 & 657 & 0.58 \\
\hline \hline
\end{tabular}


Harkanwal P. S. S. [4] reported cold plasma has a positive effect on bread structural and mechanical properties. The flour exposed for $30 \mathrm{~min}$ as well as for 45 min increased crumb cells, improved gas retention properties of dough which has resulted in a greater specific and total loaf volumes along with enhancement of their appearance and porosity structure than bread from control flour. Data in Table 3 presented that baking just after flour treatment has better results obtained from exposure to $45 \mathrm{~min}$ but not significantly different in compared with bread made from expose to 30 min.

\section{CONCLUSIONS}

Cold plasma is not accumulated in end-used products. As the cold plasma is produced just before usage, there are no requirements either for storage or activation procedure.

Treated flour with cold plasma for $30 \mathrm{~min}$ as well as for $45 \mathrm{~min}$ had a brightly creamy color, unlike untreated flour.

The results obtained showed the expose of wheat flour to cold plasma for $30 \mathrm{~min}$ or $45 \mathrm{~min}$ increases dough stability and dough strength, reduces dough softening, increases deformation energy (W) as well as index of swelling, versus control flour sample

Bread made from flour exposed to cold plasma for $30 \mathrm{~min}$ or $45 \mathrm{~min}$ has a higher specific and total loaf volume, whiter crumb versus that made from control flour.

\section{REFERENCES}

[1] Sandhu, H. P., Manthey, F. A., Simsek, S.: Quality of bread made from ozonated wheat (Triticum aestivum L.) flour. Journal Science of Food and Agriculture, Jul; 91 (9):1576-84. doi: 10.1002/jsfa.4350. Epub 2011 Mar 28. (2011).

[2] Violleau, F., Pernot, A.-G., Surel, O.: Effect of Oxygreen wheat ozonation process on bread dough quality and protein solubility. Journal of Cereal Science, 55 (3), 392396 (2012)

[3] Chittrakorn, S.: Use of ozone as an alternative to chlorine for treatment of soft wheat flours. $\mathrm{PhD}$ thesis, Kansas State University, Manhattan, USA, 2008,

[4] Harkanwal P. S. S.: Effect of ozone on wheat flour functionality and bread making quality. $\mathrm{PhD}$ thesis, Abstract (2011). 